\title{
Non-traumatic epidural posterior fossa hematomas in child with Sensenbrenner syndrome: a case report and literature review
}

\author{
Mariana Mazzuia Guimarães, Daniel Dante Cardeal, José Erasmo Dal Col Lucio, Felipe Hada \\ Sanders, Gustavo Correa Lordelo, Manoel Jacobsen Teixeira, Hamilton Matushita
}

Division of Pediatric Neurosurgery, Department of Neurosurgery, Hospital das Clínicas, School of Medicine, University of São Paulo, Brazil

To whom correspondence should be addressed: Mariana Mazzuia Guimarães, MD

e-mail:

marianamguima@yahoo.com.br

Available at:

http://www.archpedneurosurg.com.br/
Background: Posterior fossa extradural hematomas are an uncommon condition with more than half of cases appearing in the pediatric population. Although the majority of cases are caused by substantial trauma, it may also be related to systemic diseases and bleeding disorders without the history of head trauma.

Case report: We present the case of a 6-year-old female affected by Sensenbrenner syndrome with a non-traumatic subacute posterior fossa epidural hematoma. The patient was surgically treated and medically discharged without further neurological alteration. This is the first report of spontaneous cerebral hematoma associated with this syndrome in the literature. A literature review of the main aspects of both topics was performed.

Conclusions: Although spontaneous posterior fossa epidural hematomas are rare, clinicians should be aware and highly suspicious of this differential diagnosis in certain situations such as coagulopathies and other specific systemic diseases, as fast recognition and assertive treatment are important for better outcomes.

Keyworks: Epidural hematoma. Coagulopathy. Bleeding diathesis. Sensenbrenner syndrome. Ciliopathy

\section{INTRODUCTION}

Posterior fossa extradural hematomas (PFEDH) are an infrequent condition, representing between $1.2 \%$ and $15 \%$ of all extradural hematomas that occur in the general population. More than half of the cases are observed in children and adolescents [1,2].

Although the majority of cases are caused by substantial trauma, PFEDH may also be related to systemic diseases and bleeding disorders, with or without minor head trauma [2].

Due to the rareness of the condition and the possibility of neurological deterioration, this article intends to review the literature on the topic and to report the case of a child affected by a syndromic condition called Sensenbrenner syndrome, who presented with a non-traumatic epidural bleeding episode.

\section{EXEMPLARY CASE DESCRIPTION}

The patient was a 6-year-old female affected by Sensenbrenner syndrome, who had recently been hospitalized with a non-traumatic posterior fossa epidural hematoma.

Her medical history included a premature birth at 33 weeks' gestation due to oligohydramnios. Soon after birth, physical examination showed characteristic phenotypical aspects, such as brachydactyly, narrow thorax, short long bones and syndromic facial appearance. In addition, liver and renal dysfunctions were diagnosed, characterized by bile duct cysts, portal hypertension, ascites and nephronophthisis.

In the following year, other clinical signs were observed, such as sparse hair and lashes, small teeth, short stature, short nose, depressed nasal bridge, small mouth and a trigonocephaly appearance. At that time, Sensenbrenner syndrome was diagnosed. 
Non-traumatic epidural posterior fossa hematomas in child with Sensenbrenner syndrome: a case report and literature review

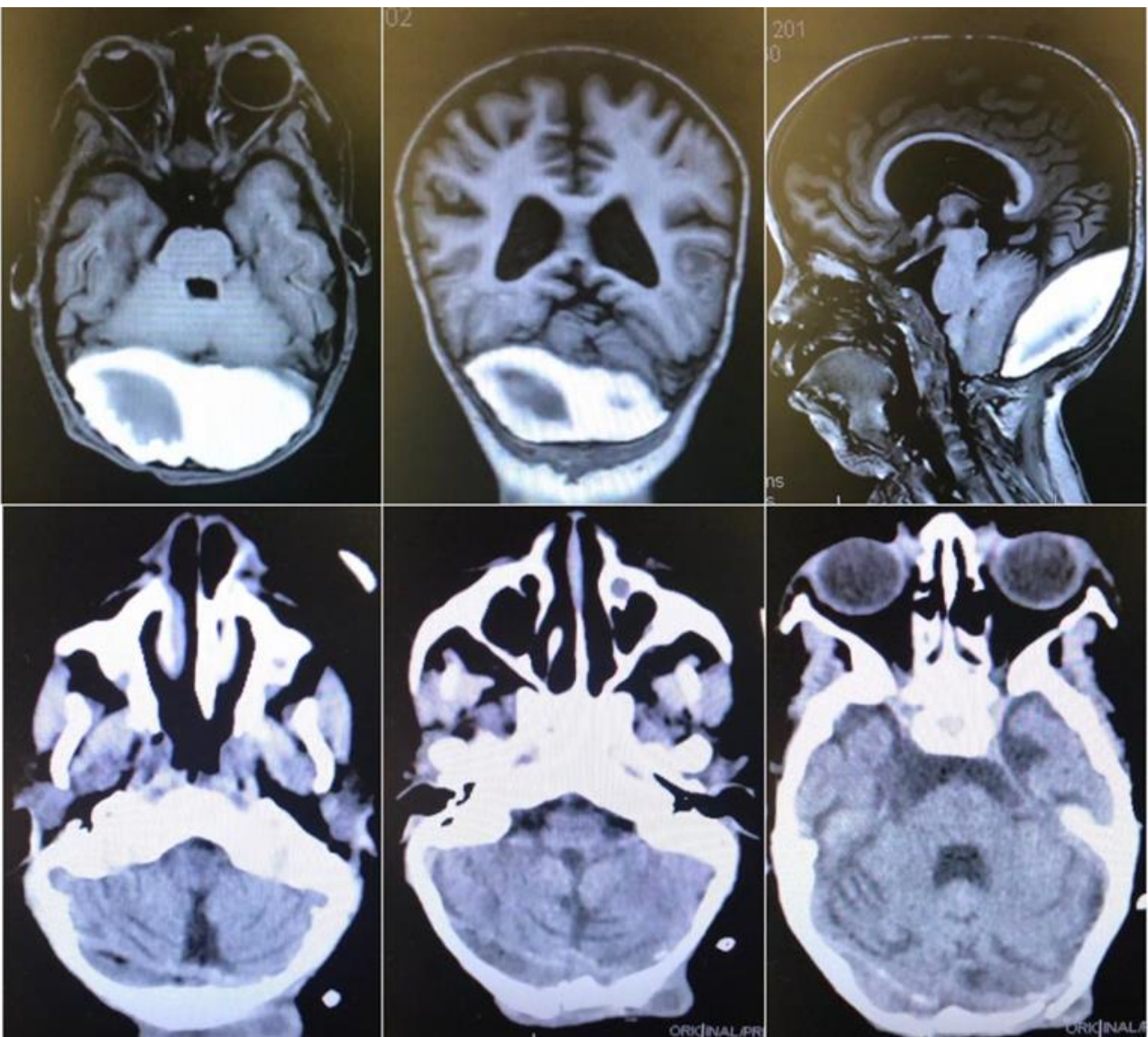

Fig 1. ABOVE - Magnetic resonance imaging (MRI) T1 weighted in axial, coronal and sagittal view demonstrating extensive heterogeneous biconvex subacute epidural hematoma in the posterior fossa. BELOW - postoperative brain computed tomography scan (CT) in axial view demonstrating complete hematoma evacuation.

Regarding the recent hospitalization, the patient presented to the emergency room 2 days after her most recent hemodialysis session with abdominal pain, constipation and drowsiness. There was no history of trauma. The first laboratory tests revealed hyperammonemia, coagulopathy and pancreatitis. After reversing the clinical changes, the patient showed no improvement in consciousness level and was submitted to further neurological investigation.

During the neurological examination, the patient was mildly sedated with reactive and adequate pupils, without other changes. Due to institutional technical peculiarities, magnetic resonance imaging (MRI) was the preferred diagnostic method and showed extensive subacute epidural hematoma in the posterior fossa (Figure 1).

Since the patient presented with uncoagulable blood test, reduced prothrombin index and elevated International normalized ratio (INR), coagulopathy reversion with vitamin $\mathrm{K}$, transfused plasma and platelets were promptly used. A posterior fossa craniotomy was performed, the hematoma was drained, dura-mater was anchored to the bone and a subcutaneous drain was placed. During the surgery, there were no vascular abnormalities observed and no further complications. A brain computed tomography scan (CT) scan was performed in the 12-hour postoperative period without evidence of rebleeding (Figure1). There was no extubation delay during the intensive care stay.

In the last follow-up, the patient's neurological function had returned to the previous level, consisting of a delayed neuropsychomotor development but with some comprehension and speech functionality. Figure 1 presents the postoperative computed tomography (CT) scan.

\section{BACKGROUND}

\section{Sensenbrenner syndrome}

Sensenbrenner syndrome, also known as cranioectodermal dysplasia (CED) type I, is a rare genetic disorder in the group of ciliopathies. Since its first description by Sensenbrenner in 1975, fewer than 60 cases have been reported in the literature $[3,4]$. This disease is generally inherited in an autosomal recessive manner. Pathogenic variants in IFT122 (previous WDR10), WDR35 (IFT121), WDR19 (IFT144) or IFT43 genes can be identified in $40 \%$ of the affected patients [5].

Defects in intraflagellar transport can impact almost all cells of the human body, especially transducing signals in the 
Non-traumatic epidural posterior fossa hematomas in child with Sensenbrenner syndrome: a case report and literature review

Hedgehog (Hh), Wnt and fibroblast growth factor (FGF) pathways, which play important roles during embryogenesis $[3,6]$. The wide range of abnormalities might be responsible for the heterogeneity of this syndrome and the variety of phenotypes observed $[7,8]$.

Thereat, Lin et al. proposed the "cardinal findings" of this syndrome, including brachydactyly, ectodermal abnormalities (small, wide-spaced teeth, hypo/oligodontia, sparse hair, short nails), distinctive facial appearance, sagittal craniosynostosis, narrow thorax, joint laxity and limb shortness. Renal and hepatic insufficiency can also be observed [8].

Regarding neurological findings, the majority of patients present with dolichocephaly; however, other types of craniosynostosis, such as oxycephaly, have also been described $[5,9]$. These alterations are often severe and can be seen at birth or even prenatally $[5,10]$. Developmental milestones might be delayed, although this is uncommon and exclusively related to WDR35 mutations $[7,8]$.

Craniofacial alterations can be characterized by low-set rotated ears, telecanthus, epicanthal folds and/or palpebral fissures. Full checks, micrognathia, everted lower lip and anteverted nares can also be present. The remaining changes are mostly related to cranial vault synostoses, usually presenting as frontal bossing and a 'boxing' head [3, $4,5,11]$.

Gastrointestinal bleeding has been previously described in relation to liver dysfunction in two affected patients [7, 12]. However, until now, no reports of spontaneous cerebral hematoma related to this syndrome had been published in the literature.

\section{Posterior fossa extradural hematoma (PFEDH)}

A literature search was conducted using MedLine database combining the terms "posterior fossa extradural hematoma" and "posterior fossa epidural hematoma" to "spontaneous", "non-traumatic", "pediatric" and/or "children" published in the last five decades. In general, PFEDH occurs infrequently [1, 2, 13, 14, 15, 16, 17]. Moreover, non-traumatic PFEDH is extremely unusual, with only a few reports published in the literature $[18,19,20,21$, $22,23,24,25]$.

Kaushik and Sandip reviewed 41 articles on pediatric PFEDH published between 1953 and 2017 and described a rare association with bleeding diathesis, systemic illness, cardiac surgery and malignancy, while $73 \%$ to $93 \%$ of the patients had suffered occipital fractures due to head trauma [2]. In children, in whom occipital fracture is more common and the dura is more strongly attached to the skull and consequently more injury susceptible, traumatic PFEDH occurs up to three times more frequently $[2,18]$.
Inherited or acquired coagulopathy is usually present in spontaneous central nervous system (CNS) bleeding episodes [26, 27, 28]. Other systemic pathologies, such as neoplasms, can also be observed [2, 20-22].

Table 1 presents the literature studies that report cases of pediatric patients with spontaneous PFEDH and associated conditions that facilitated bleeding. There were only two children, aged 4 and 12 years, in whom PFEDH were completed disassociate with trauma and was due to full heparinization before cardiac surgery and angiosarcoma spontaneous hematoma, respectively $[18,22]$. The remaining patients were affected by bleeding disorders or other conditions with a higher risk of hemorrhages [19, 2325]. It is important to highlight that these patients were linked to mild trauma, which would unlikely cause a bleeding episode in a patient with normal coagulation function or healthy blood vessels.

\section{CLINICAL PRESENTATION}

The clinical manifestations of spontaneous PFEDH can be variable and non-specific. Usually, they are dependent on the hematoma volume, obstructive hydrocephalus and brain stem compression.

In the majority of the reported cases, headache, nausea and vomiting were present initially, followed by altered sensorium and drowsiness [18, 19, 22-25]. Nuchal rigidity, hemiparesis, incoordination, pupil alteration, bradycardia and deep coma have also been described [18, 20, 22, 23].

Similarly, Balik et al. reported headache, disorientation and coma as the three most frequent symptoms. Nausea, vomiting, dysphasia, hemiparesis, dizziness, seizures and mydriasis were also observed in some of the patients [1]. Kaushik and Sandip shared this view, and also reported rapid neurological deterioration due to brain stem compression and hydrocephalus [2].

The duration of symptoms varies from hours to days and may be related to the etiopathogenesis. Inherited coagulopathy, such as hemophilia A and Von Willebrand's disease, is more frequently associated with acute onset [19, 24, 25]. Neoplastic conditions, such as angiosarcoma and skull metastasis from hepatocellular carcinoma have also been reported to present in the same way [21, 22]. On the other hand, the PFEDH related to mastoiditis and sinus thrombosis, presented with a subacute onset [20].

\section{DIAGNOSIS}

The diagnosis of epidural hematoma diagnosis can be obtained faster by a CT scan, making it the preferred method; however, MRI has similar efficacy, in addition to being more suitable for diagnosing non-acute neurological 
Non-traumatic epidural posterior fossa hematomas in child with Sensenbrenner syndrome: a case report and literature review

Table 1. Detailed description of the mentioned cases of posterior fossa extradural hematoma in children.

\begin{tabular}{|c|c|c|c|c|c|c|}
\hline & $\begin{array}{c}\text { Age } \\
\text { (years) }\end{array}$ & $\begin{array}{l}\text { Associated } \\
\text { condition }\end{array}$ & $\begin{array}{c}\text { Clinical } \\
\text { presentation }\end{array}$ & Diagnosis & Management & Outcome \\
\hline $\begin{array}{l}\text { Frydrych et } \\
\text { al., } 1981\end{array}$ & 4 & $\begin{array}{c}\text { Hemophilia A } \\
+ \\
\text { mild trauma }\end{array}$ & Drowsiness & $\begin{array}{c}\text { CT } \\
\text { Coag alt }\end{array}$ & $\begin{array}{l}\text { Suboccipital } \\
\text { craniectomy and } \\
\text { clot evacuation }\end{array}$ & $\begin{array}{l}\text { Neurologically } \\
\text { intact }\end{array}$ \\
\hline $\begin{array}{c}\text { Ohishi et al., } \\
1983\end{array}$ & 9 & $\begin{array}{c}\text { Hemophilia A } \\
+ \\
\text { mild trauma }\end{array}$ & $\begin{array}{l}\text { Headache } \\
\text { and nausea }\end{array}$ & $\begin{array}{c}\text { CT } \\
\text { Coag alt }\end{array}$ & $\begin{array}{l}\text { Suboccipital } \\
\text { craniectomy and } \\
\text { clot evacuation }\end{array}$ & $\begin{array}{l}\text { Neurologically } \\
\text { intact }\end{array}$ \\
\hline $\begin{array}{c}\text { Ohishi et al., } \\
1983\end{array}$ & 10 & $\begin{array}{c}\text { Hemophilia A } \\
+ \\
\text { mild trauma }\end{array}$ & $\begin{array}{l}\text { Headache } \\
\text { and nausea }\end{array}$ & $\begin{array}{c}\text { CT } \\
\text { Coag alt }\end{array}$ & $\begin{array}{l}\text { Suboccipital } \\
\text { craniectomy and } \\
\text { clot evacuation }\end{array}$ & $\begin{array}{l}\text { Neurologically } \\
\text { intact }\end{array}$ \\
\hline $\begin{array}{c}\text { Takenaka et } \\
\text { al., } 1988\end{array}$ & 9 & $\begin{array}{c}\text { Von } \\
\text { Willebrand's } \\
\text { disease } \\
+ \\
\text { mild trauma }\end{array}$ & $\begin{array}{c}\text { Vomiting } \\
\text { and drowsiness }\end{array}$ & $\begin{array}{c}\text { CT } \\
\text { Coag alt }\end{array}$ & $\begin{array}{l}\text { Suboccipital } \\
\text { craniectomy and } \\
\text { clot evacuation }\end{array}$ & $\begin{array}{l}\text { Neurologically } \\
\text { intact }\end{array}$ \\
\hline $\begin{array}{c}\text { Mandera et } \\
\text { al., } 2003\end{array}$ & 10 & $\begin{array}{l}\text { Hutchinson- } \\
\text { Gilford progeria } \\
\text { syndrome } \\
+ \\
\text { mild trauma }\end{array}$ & $\begin{array}{l}\text { Drowsiness, } \\
\text { divergent } \\
\text { positioning of } \\
\text { the optic bulbs } \\
\text { and } \\
\text { hemiparesis* }\end{array}$ & $\mathrm{CT}$ & $\begin{array}{l}\text { Suboccipital } \\
\text { craniectomy, } \\
\text { clot evacuation } \\
\text { and temporal } \\
\text { craniotomy }\end{array}$ & $\begin{array}{r}\text { Residual } \\
\text { hemiparesis }\end{array}$ \\
\hline $\begin{array}{l}\text { Ahmad et } \\
\text { al., } 2005\end{array}$ & 4 & $\begin{array}{l}\text { After cardiac } \\
\text { surgery }\end{array}$ & $\begin{array}{l}\text { Drowsiness } \\
\text { and deep coma }\end{array}$ & $\begin{array}{c}\text { CT } \\
\text { Coag alt }\end{array}$ & $\begin{array}{l}\text { Suboccipital } \\
\text { craniectomy and } \\
\text { clot evacuation }\end{array}$ & $\begin{array}{l}\text { Neurologically } \\
\text { intact }\end{array}$ \\
\hline $\begin{array}{l}\text { Mahore et } \\
\text { al., } 2014\end{array}$ & 12 & $\begin{array}{l}\text { Angiosarcoma } \\
\text { first presentation }\end{array}$ & $\begin{array}{l}\text { Headache, } \\
\text { vomiting, } \\
\text { nuchal rigidity } \\
\text { and } \\
\text { bradycardia }\end{array}$ & $\begin{array}{l}\mathrm{CT} \\
\mathrm{MRI}\end{array}$ & $\begin{array}{l}\text { Suboccipital } \\
\text { craniotomy, clot } \\
\text { evacuation and } \\
\text { tumor excision }\end{array}$ & $\begin{array}{l}\text { Neurologically } \\
\text { intact }\end{array}$ \\
\hline
\end{tabular}

conditions such as brain stem injury or basal ganglia involvement in sustained unresponsiveness [1, 2, 15-18].

Kaushik and Sandip recommend CT as the gold standard for diagnosis, but highlight the importance of MRI and magnetic resonance venogram in dural sinus injury and when there is suspicion of posterior fossa alteration [2].
Considering the cited cases in this study, a CT scan was the first choice in all cases [18, 19, 22-25]. A MRI scan was added in a challenging case [22].

Determination of the coagulation profile is essential for both clinical suspicion and treatment efficiency. In the published cases, five of seven had a coagulation alteration and one of the two remaining patients was believed to have 
Non-traumatic epidural posterior fossa hematomas in child with Sensenbrenner syndrome: a case report and literature review

bleeding caused by atherosclerosis-related to progeria syndrome $[18,19,23-25]$.

\section{MANAGEMENT}

Zakaria et al. provided a management algorithm for PFEDH in the general population. They found that $85 \%$ of PFEDH cases are of venous origin and could therefore be conservatively managed depending on the conscious level, presence of focal deficits, volume and midline shift [17]. Similarly, other authors agreed with this conservative approach and stressed the importance of neurological monitoring $[2,29]$.

Hematomas larger than $10 \mathrm{~mm}$, cisternal obliteration, forth ventricle distortion and brain stem compression are indicative of neurosurgical drainage. In some subacute or chronic cases, non-invasive management can be chosen depending on the neurologic exam. However, suboccipital craniectomy and evacuating the epidural clot was preferred in the majority of the pediatric series $[2,18]$.

All patients included in this series were surgically managed. Discreet delays in surgery were related to reversion of bleeding diathesis [18, 19, 22-25].

\section{PROGNOSIS AND OUTCOMES}

The mortality and morbidity rates of PFEDH are high, especially if patients are not treated by neurologically trained staff. The worst results are associated with the lowest scores on the preoperative Glasgow Coma Scale, pupillary mydriasis or asymmetries and the presence of other related lesions. However, total recovery can be achieved especially in children who undergo surgical clot evacuation and assertive hematological assistance $[2,13,14$, $17,18]$

All patients described in this series were discharged without neurological deficits, except for one case of residual hemiparesis, which may have been associated with a supratentorial hematoma [23].

\section{CONCLUSIONS}

Despite the rareness of PFEDH, clinical suspicion should be raised specially in patients with altered coagulation presenting with deterioration in neurological status, with or without mild head trauma. Early recognition and fast treatment are important for better neurological outcomes.

\section{COMPLIANCE WITH ETHICAL STANDARDS}

Disclosures: The authors declare that they have no conflict of interest. All authors certify that they have no affiliations with or involvement in any organization or entity with any financial interest or non-financial interest in the subject matter or material discussed in this manuscript.
Ethical approval: The patient's guardian has consented to the submission of the case report and photographs to the journal. Detailed informed consent was provided.

Funding: The cost relating to professional proofreading was funded by the researcher. They were no other costs. No funding was received for this research.

\section{REFERENCES}

1. Balik V, Lehto H, Hoza D, Sulla I, Hernesniemi J. Posterior fossa extradural haematomas. Cent Eur Neurosurg. 2010; 71(4):167-172. http://doi.org/10.1055/s-00301249046

2. Kaushik S, Sandip C. Posterior Fossa Acute Extradural Hematoma in Children: Review and Management Guidelines. J Pediatr Neurosci. 2018; 13(3):289-293. http://doi.org/10.4103/JPN.JPN_86_18

3. Walczak-Sztulpa J, Eggenschwiler J, Osborn D, et al. Cranioectodermal Dysplasia, Sensenbrenner syndrome, is a ciliopathy caused by mutations in the IFT122 gene. Am J Hum Genet. 2010; 86(6):949-956. http://doi.org/10.1016/j.ajhg.2010.04.012

4. Walczak-Sztulpa J, Wawrocka A, Swiader-Lesniak A, et al. Clinical and molecular genetic characterization of a male patient with Sensenbrenner syndrome (cranioectodermal dysplasia) and biallelic WDR35 mutations. Birth Defects Res. 2018; 110(4):376-381. http://doi.org/10.1002/bdr2.1151

5. Arts $\mathrm{H}$, Knoers N. Cranioectodermal Dysplasia. In: Adam $\mathrm{MP}$, Ardinger $\mathrm{HH}$, Pagon RA, et al., editors. GeneReviews ${ }^{\circledR}$. Seattle (WA): University of Washington, Seattle. 2013. Available via: https://www.ncbi.nlm.nih.gov/books/NBK154653/ Accessed 20 Jul 2020

6. Córdova-Fletes C, Becerra-Solano LE, Rangel-Sosa MM, et al. Uncommon runs of homozygosity disclose homozygous missense mutations in two ciliopathyrelated genes (SPAG17 and WDR35) in a patient with multiple brain and skeletal anomalies. Eur J Med Genet. 2018; 61(3):161-167. http://doi.org/10.1016/j.ejmg.2017.11.011

7. Bacino CA, Dhar SU, Brunetti-Pierri N, Lee B, Bonnen PE. WDR35 mutation in siblings with Sensenbrenner syndrome: a ciliopathy with variable phenotype. Am J Med Genet A. 2012; 158A(11):2917-2924. http://doi.org/10.1002/ajmg.a.35608

8. Lin $A E$, Traum $A Z$, Sahai I, et al. Sensenbrenner syndrome (Cranioectodermal dysplasia): clinical and molecular analyses of 39 patients including two new patients. Am J Med Genet A. 2013; 161A(11):2762-2776. http://doi.org/10.1002/ajmg.a.36265

9. Genitori L, Lang G, Philip N, Cavalheiro S, Lena G, Choux M. Cranioectodermal dysplasia with sagittal craniosynostosis (Sensenbrenner's syndrome): case 
Non-traumatic epidural posterior fossa hematomas in child with Sensenbrenner syndrome: a case report and literature review

report and review of the literature. British Journal of Neurosurgery. 1992; 6, 601-606

10. Harada A, Miyashita S, Nagai R, Makino S, Murotsuki J. Prenatal sonographic findings and prognosis of craniosynostosis diagnosed during the fetal and neonatal periods. Congenit Anom (Kyoto). 2019; 59(4):132-141. http://doi.org/10.1111/cga.12308

11. Girisha KM, Shukla A, Trujillano D, et al. A homozygous nonsense variant in IFT52 is associated with a human skeletal ciliopathy. Clin Genet. 2016; 90(6):536-539. http://doi.org/10.1111/cge.12762

12. Ackah RL, Yoeli D, Kueht M, Galván NTN, Cotton RT, Rana A, O'Mahone CA, Goss JA. Orthotopic liver transplantation for Sensenbrenner syndrome. Pediatr Transplant. 2018; e13077. http://doi.org/10.1111/petr.13077

13. Chaoguo Y, Xiu L, Liuxun H, Hansong S, Nu Z. Traumatic Posterior Fossa Epidural Hematomas in Children : Experience with 48 Cases and a Review of the Literature. J Korean Neurosurg Soc. 2019; 62(2):225-231. http://doi.org/10.3340/jkns.2016.0506.007

14. Ciurea, A.V., Nuteanu, L., Simionescu, N. et al. Posterior fossa extradural hematomas in children: report of nine cases. Child's Nerv Syst. 1993; 9, 224-228. http://doi.org/10.1007/BF00303574

15. Malik NK, Makhdoomi R, Indira B, Shankar S, Sastry K. Posterior fossa extradural hematoma: our experience and review of the literature. Surg Neurol. 2007; 68:1558. http://doi.org/10.1016/j.surneu.2006.10.051

16. Winter RC, Pollock MD, Avrum N. Posterior fossa epidural hematoma. Pediatr Emerg Care. 2015; 31:8089. http://doi.org/10.1097/pec. 0000000000000613

17. Zakaria Z, Kaliaperumal C, Kaar G, O'Sullivan M, Marks C. Extradural haematoma- To evacuate or not? Revisiting treatment guidelines. Clinical Neurology and Neurosurgery. 2013; 115, 1201-1205. http//.doi.org/10.1016/j.clineuro.2013.05.012

18. Ahmad FU, Pandey P, Mahapatra AK. Spontaneous posterior fossa extradural hematoma--a rare complication following cardiac surgery. Pediatr Neurosurg. 2005; 41(1):49-51. http://doi.org/10.1159/000084866

19. Frydrych A, Wencel T, Białas J, Majchrzak H, Zyciński A. Post-traumatic hematoma of the posterior cranial fossa in a 4-year-old boy with hemophilia A. Neurol Neurochir Pol. 1981; 15:101-4
20. Kaif, M. Mastoiditis causing sinus thrombosis and posterior fossa epidural haematoma: case report. Sultan Qaboos Univ Med J. 2011; 11(1):108-11.

21. Kim YS, Moon KS, Lee KH, Jung TY, Jang WY, Kim IY, Jung S. Spontaneous acute epidural hematoma developed due to skull metastasis of hepatocellular carcinoma: A case report and review of the literature. Oncology Letters. 2016; 11: 741-744. http://doi.org/10.3892/ol.2015.3947

22. Mahore A, Ramdasi RV, Pauranik A, Epari S. Tumour bleed manifesting as spontaneous extradural haematoma in posterior fossa. BMJ Case Rep. 2014; Jul 9. http://doi.org/10.1136/bcr-2014-205175

23. Mandera $M$, Larysz D, Pajak J, Klimczak A. Epidural hematomas in a child with Hutchinson-Gilford progeria syndrome. Childs Nerv Syst. 2003; 19(1):63-65. http://doi.org/10.1007/s00381-002-0679-8

24. Ohishi H, Onuma T, Mizoi K, Mori K. Acute epidural hematoma in the posterior fossa in patients with hemophilia A-report of two surgically treated cases. No Shinkei Geka. 1983; 11:659-64

25. Takenaka N, Mine T, Ikeda E, Iwai H, Kusano S. Acute epidural hematoma of the posterior fossa in a case of von Willebrand's disease. No Shinkei Geka. 1988; 16:529-33

26. Finger $G$, Martins OG, Basso LS, Ludwing do Nascimento T, Schiavo FL, Cezimbra dos Santos S, Stefani MA. Acute spontaneous subdural hematoma in posterior fossa: case report with great outcome, World Neurosurgery. 2018; 119:146-150. http://doi.org/10.1016/j.wneu.2018.07.220

27. Sahlu A, Getachew K, Mekonnen A. Traumatic Retroclival Subdural Hematoma in a Child with Hemophilia. World Neurosurg. 2020; 133:112-120. http://doi.org/10.1016/j.wneu.2019.09.059

28. Siboni SM, Zanon E, Sottilotta D, Consonni D, Castaman G, Mikovic D, Biondo F, Tagliaferri A, lorio A, Mannuci PM, Peyvandi F. Central nervous system bleeding in patients with rare bleeding disorders. Haemophilia. 2012; 18, 34-38. http://doi.org/10.1111/j.13652516.2011.02545.x

29. 29. Pang D, Horton JA, Herron JM, Wilberger JE, Vries Jk. Nonsurgical management of extradural hematomas in children. J Neurosurg. 1983; 59: 958-71. http://doi.org/10.3171/jns.1983.59.6.0958 